IRSH 55 (2010), pp. 63-8 I doi:10.I0I7/S0020859009990629

(C) 2010 Internationaal Instituut voor Sociale Geschiedenis

\title{
Scottish Labour, Race, and Southern African Empire c. I880-I922: A Reply to Kenefick
}

\author{
JONATHAN HYSLOP \\ Wits Institute of Social and Economic Research, University of the \\ Witwatersrand
}

E-mail: Jonathan.Hyslop@wits.ac.za

Summary: In his article in the current edition of International Review of Social History, the Scottish historian, Billy Kenefick, argues against my thesis that the labour force of the United Kingdom and the settler colonies in the late nineteenth and early twentieth centuries can be understood as having constituted a linked "imperial working class" in which an ideology of racialized white labour protectionism predominated. Kenefick believes that in South Africa British socialists challenged white labourism, and that Scottish immigrants played a very prominent role in this anti-racist project. My reply traces the relationship between Scottish national identity, imperialism, and the labour movement. It then examines the evidence on the racial politics of Scottish trade unionists in South Africa and argues that, with a very few individual exceptions, they did buy into the ideas of white labourism. Finally, the article considers Scottish labour attitudes to race in the home country, and demonstrates that there was strong sympathy for the racial labour politics of the settler colonies.

In his article criticizing my work on the role of racial ideology in the preWorld-War-I labour movement of Britain and its diaspora, the Scots historian Billy Kenefick argues against my thesis that the labour force of the United Kingdom and the settler colonies can be understood as having constituted a linked "imperial working class" in which an ideology of "white labourism" predominated. ${ }^{\mathrm{I}}$ In my view, white labourism, combining

I. Jonathan Hyslop, “The Imperial Working Class Makes Itself 'White': White Labourism in Britain, Australia, and South Africa Before the First World War", Journal of Historical Sociology, I 2 (1999), pp. 398-42 I; idem, "A Scottish Socialist Reads Carlyle in Johannesburg Prison, June 1900: Reflections on the Literary Culture of the Imperial Working Class", Journal of Southern African Studies, 29 (2003), pp. 639-655; idem, The Notorious Syndicalist-J.T. Bain: A Scottish Rebel in Colonial South Africa (Johannesburg, 2004); and idem, "The World Voyage of James Keir Hardie: Indian Nationalism, Zulu Insurgency and the British Labour Diaspora 1907-1908”, Journal of Global History, I (2006), pp. 343-362. 
anti-capitalist militancy with racial protection of white workers' jobs against the competition of Asian and African labour, was the hegemonic (although by no means the only) ideology of British labour at home and abroad.

Kenefick, by contrast, believes that in South Africa "[British] nonracialists and anti-segregationists did mount a serious challenge to the prevailing ideology of white labourism and through the dissemination of local and international left-radical, socialist and revolutionary syndicalist newspapers they offered South African workers an alternative to the industrial policy of racial segregation.” And he contends that there was a particular ethnic dynamic at work in this anti-racist trend:

$[\ldots]$ in this determined drive to undermine the ideology of white labourism, the movement was disproportionately influenced by radical left Scottish migrants who firmly adhered to the colour-blind principles of international socialism, industrial unionism and revolutionary syndicalism, and in doing so formed an anti-racialist vector which confronted the system of racial and industrial segregation $[\ldots]$.

Drawing on Lucien van der Walt's critique of southern African labour historiography, ${ }^{2}$ Kenefick argues that my perspective is unduly under the sway of what Van der Walt calls the "communist school", which has portrayed South African labour organizations in the pre-I9I4 period as exclusively reactionary, thereby presenting the role of the Communist Party after its foundation in I92 I in the best possible light. ${ }^{3}$

Billy Kenefick makes a useful contribution to historical debate. I welcome his careful reading of my work, and I am not one of those scholars who feels obliged to defend every line he has ever written. I have modified my argument from its initial, perhaps overly stark formulation in my 1999 article. Nevertheless, I will argue that Kenefick's work does not overturn my fundamental proposition that in the period between the r880s and World War I, an ideology of white labourism prevailed in the British emigrant labour movements of Australasia, southern Africa, and North America, and in British unions. I am in agreement with Kenefick and John MacKenzie ${ }^{4}$

2. Lucien van der Walt, “'The Industrial Union is the Embryo of the Socialist Commonwealth': The International Socialist League and Revolutionary Syndicalism in South Africa, I91 5-1919”, Comparative Studies of South Asia, Africa and the Middle East, I9 (1999), pp. 5-28; idem, "'Bakunin's Heirs in South Africa': Race, Class and Revolutionary Socialism from the IWW to the International Socialist League, 1910-192 I", Politikon: The South African Journal of Political Studies, 30 (2004), pp. 67-89; idem, "The First Globalisation and Transnational Labour Activism in Southern Africa: White Labourism, the IWW and the ICU, I904-1934", African Studies, 66 (2007), pp. 233-25 I.

3. The key text in the communist school is H.J. and R.E. Simons, Class and Colour in South Africa, I850-1950 (Harmondsworth, I969).

4. John A. MacKenzie with Nigel R. Dalziel, The Scots in South Africa: Ethnicity, Identity, Gender and Race, I772-1914 (Manchester, 2007). 
that the Scots played an extremely important role in the southern Africa of the period, and that the Scottish working class (especially its skilled artisans) were crucial to the economy and labour organization of the region. But while Kenefick is right to suggest that the specificity of Scots identity within the labour movement is important to investigate, I dispute his implication that Scots workers, either in South Africa, or in Britain, were especially well disposed toward racial egalitarianism.

The differences between us are to some extent around the weight which we put on particular strands of the evidence. I accept that there were a number of Scots labour leaders, in South Africa and in Scotland, who took anti-racist positions. But where I part company with Kenefick is that I do not believe that they had much direct influence on the mass membership of the labour movement. There is no evidence that progressive organizers were able to gain support for their views on race amongst white workers in South Africa in general, or amongst Scots immigrants in particular. When the South African Labour Party (SALP) was formed on a segregationist basis in I909, it attracted the support of most recent English and Scottish working-class immigrants and held their allegiance for several decades thereafter. In Scotland itself, there was indeed a rise in workingclass anti-imperial sentiment in the labour movement in Scotland in the I920s and I930s, but that should not be projected back in time to the first two decades of the century.

I want to say immediately that I am not in the business of making anachronistic moral judgements. The Scottish labour activists of our period need to be understood in the context of their times. They were complex, interesting, and in some cases heroic individuals who deserve an effort of comprehension on our part. But by the same token, we should be careful not to reinvent early twentieth-century individuals as exemplifying early twenty-first-century ideas of egalitarian virtue. We ought not to be led by a sense of empathy with those historical movements we are studying, into denying the inegalitarian effects of some of the policies they advocated. And we should not assume that hostility to capitalism is necessarily based on opposition to racial inequality.

Kenefick's argument is uneasily located between class essentialism and nationalism. He portrays workers as naturally responsive to non-racism and internationalism, a position which seems to me to derive from classical Marxist notions of workers as a universal class, a revolutionary subject, and a class without a country. But on the other hand, there is also a nationalist tinge to Kenefick's views as well, in that he seems to see a particular egalitarianism inherent in the Scottish working class. I think that we should avoid any such a priori assumptions about the inherent political nature of a class or ethnic-national group.

I feel that Kenefick somewhat misses the point of Van der Walt's critique of the "communist school" in suggesting that I base myself on that school's 
approach. Van der Walt contends that South African Communist Party historians, and especially H.J. and R.E. Simons, whose 1969 book Class and Colour in South Africa,' has canonical status in the historiography, systematically distorted the historical record to exclude anything at variance with party positions. Moreover, Van der Walt argues, the ideas of revolutionary syndicalism, rather than Marxism, influenced a large portion of the South African left before the early i 920 .

I actually concur with Van der Walt on his methodological criticisms of the Communist Party historians, and accept his evidence that they did everything possible to ignore evidence of anti-racist politics amongst earlier, syndicalist, labour activists and to embellish the (really quite equivocal) anti-racist credentials of the first years of the party. Equally, I think that Van der Walt is correct to say that syndicalist ideas were widespread in the international labour movement before World War I, and that they had a noticeable influence in South Africa. And I accept that some South African revolutionary syndicalists developed a "critique of racism" and white labourism. So I am at one with Van der Walt on most aspects of his critique of the communist school. Where I do differ with Van der Walt (and with Kenefick) is specifically on the point that I do not think that the critical stance of these activists toward racism had any substantial impact on the membership of the white trade unions, or of the British emigrant working class more broadly.

I will organize my response to Kenefick around three issues. Firstly, I will discuss the question of how far Scottish labour political identities, at home and abroad, were distinct from those of the rest of the British working class, and whether there was a consequent distinctiveness in its relationship to imperialism and racism. Secondly, I will consider the validity of Kenefick's case that Scots workers were protagonists of a distinctive anti-racist politics in southern Africa. Thirdly, I will critically analyse Kenefick's evidence for the strength of anti-imperial and antiracist views among the Scots working class in their home country.

\section{A DISTINCTIVE SCOTTISH LABOUR IDENTITY?}

I am sympathetic to Kenefick's call for the need for attention to be paid to the specificity of the role of the Scots in southern Africa. Indeed, I have published widely on this subject, ${ }^{6}$ precisely because I have felt that much

5. Simons and Simons, Class and Colour in South Africa.

6. Jonathan Hyslop, "Cape Town Highlanders, Transvaal Scottish: Military 'Scottishness' and Social Power in Nineteenth and Twentieth Century South Africa", South African Historical Journal, 47 (2002), pp. 96-I I4; idem, "Making Scotland in South Africa: Charles Murray, the Transvaal's Aberdeenshire Poet", in D. Lambert and A. Lester (eds), Imperial Careers Across the British Empire (Cambridge, 2006), pp. 309-334. 
of the recent historiography of British Empire settler societies (and especially the South African historiography) does not give sufficient attention to the socio-political impact of different strands of ethnic identity. ${ }^{7}$ However, Kenefick seems to believe that Scots identities were in conflict with imperial purposes in our period, whereas I would argue quite the opposite. Scots national identity was primarily aligned with the pan-British and imperial political projects from at least the time of the Napoleonic wars to the start of World War I.

As Linda Colley has demonstrated, popular investment in a common Britishness was consolidated in the late eighteenth and early nineteenth century in response to the challenge of the French Revolution and the Napoleon's Empire. ${ }^{8}$ From that period, Scots national sentiment was not a contrary force to British imperial identity, but accepted as a distinct component of it. The (re)invention of Scottish Highlander identity in the hugely influential literary work of Sir Walter Scott, involved an overcoming of the legacy of the Scottish rebellions of I7Is and I745 and the subsequent English repression of the Highland culture and polity. By romanticizing the Highlands as the basis of Scottishness, this ideology of "tartanry" provided an honourable place for previously hostile social groupings within the United Kingdom's political culture. It was Scott himself who organized the enthusiastic reception of George IV in Edinburgh in 1822 by crowds of loyal Highlanders, an event of great symbolic importance in cementing Anglo-Scottish unity. The idea of the Highlands as embodying the national identity was a typically rural-romantic one, emerging from a time when a larger and larger proportion of Scots lived in the increasingly industrialized Lowlands. But it was a highly successful and widely accepted. ${ }^{9}$

The Scottish "Highland" regiments of the British army well illustrate this process of the incorporation of Scots symbolism within a Britishnational discourse. The military prowess of the Scottish regiments became celebrated as an example of imperial loyalty. The Scots came to be seen as both a martial race in themselves, and as the outstanding fighting force of the British army. ${ }^{10}$ The fictive nature of the collapsing of the idea of Scotland into "Highlandism" is nicely illustrated by the fact that, as the nineteenth century advanced, an increasing proportion of the soldiers in

7. Donald Harman Akenson, The Irish in South Africa (Grahamstown, 199I) makes a similar point.

8. Linda Colley, Britons: Forging the Nation $1707-1837$ (New Haven, CT, 1992).

9. Charles Withers, "The Historical Creation of the Scottish Highlands", in I. Donnachie and C. Whatley (eds), The Manufacture of Scottish History (Edinburgh, 1992), pp. 143-156; T.M. Devine, Clanship to Crofters War (Manchester, I994), pp. 84-99.

I०. Heather Streets, Martial Races: The Military, Race and Masculinity in British Imperial Culture (Manchester, 2004). See also T.M. Devine, The Scottish Nation 1700-2000 (London, 2000), pp. 238-24I. 
the "Highland" regiments were actually Lowlanders, many of them of Irish origins. Scottishness and imperial loyalism were drawn together under the sign of the re-invented Highlands. As Richard J. Finlay writes, "[f]or those Scots concerned with national identity in the period before the First World War, the empire provided a tailor-made outlet for all those qualities of virility, martial prowess and romanticism which characterised much of later nineteenth century European nationalism". II

It is far from apparent that, before I9I4, the Empire was perceived by large numbers of Scots workers as contradictory to their interests. And while many Scots thought of themselves as culturally and historically different from the English, few of them saw this as requiring a separate politics: in the words of O. and S. Checkland, "there was a sense of distinctiveness which did not require the assertion of separateness". ${ }^{{ }^{2}}$ In the years leading up to World War I, the Empire provided employment opportunities and relative prosperity to at least the upper layers of the Scottish working class. Scotland was a world leader in fields of industry such as shipbuilding, railway-engine construction, and metalworking, and much of the production was for imperial market. Not for nothing was Glasgow known as the "Second City of the Empire". Scottish industry trained some of the most skilled artisans in the world, and they became the technical backbone of the new industries of Australasia, southern Africa, Canada, and other parts of the Empire.

Scots workers by and large accepted a United Kingdom political identity. Scottish trade union leaders in this period routinely referred to themselves as "British". The formation of the Scottish Labour Party in I 888 preceded the formation of a broad Labour Party in England, but it was soon absorbed by the pan-British Independent Labour Party (ILP) in I 893. The Scottish Labour Party had a formal commitment to Scottish home rule and there was a flurry of activity around this cause in the early I 890 s, but after that the issue was largely neglected by the left. The greatest Scottish labour leader of all, James Keir Hardie, saw no difficulty is being the parliamentary representative of the London constituency of West Ham, and later of the Welsh constituency of Merthyr Tydfil. ${ }^{13}$

There was a small but significant upsurge in national-identity politics amongst Scottish intellectuals after the turn of the century, particularly precipitated by the anglocentric policies of the educational authorities, but this issue does not appear to have aroused a major interest amongst

I I. Richard J. Finlay, "National Identity in Crisis: Politicians, Intellectuals and the 'End of Scotland'1920-1939", in A. Cooke, I. Donnachie, A. Macsween, and C. Whatley (eds), Modern Scottish History: 1707 to the Present, IV (East Linton, I998), p. I3.

I2. Olive and Sydney Checkland, Industry and Ethos: Scotland I832-1914 (Edinburgh, I989), p. 198 .

I3. Kenneth O. Morgan, Keir Hardie: Radical and Socialist (London, 1997). 
the working class. ${ }^{14}$ From about I910 there was substantial activity by a movement known as the Young Scots Society to demand Scots home rule, but this group was firmly aligned with the Liberal Party, and its ideology was, in any case, based on the idea of greater recognition of Scotland's place within the Empire. ${ }^{I 5}$ The point then, is that at least for the period up to World War I, there was no clear reason why a Scots cultural identification should make workers either particularly anti-imperial or particularly distinct from their English counterparts in their political sentiments.

At the turn of the century the Scots largely identified the Empire with prosperity. It was only after the Scottish heavy industries went into deep decline subsequent to World War I, that the issue of an economic divergence of Scottish and English interests became apparent and much discussed in Scottish public life. Even then, though there was now growing support for Scottish home rule, in the labour movement it remained moderate and gradualist and within the framework of a conception of Scotland as part of a British nation. Hard-core nationalist activists in the interwar years were largely middle class. ${ }^{16}$ None of this is to dispute the artificiality of the composite British state, so brilliantly analysed by Tom Nairn. ${ }^{17}$ But what Nairn wittily dubbed "Ukania" was to a significant degree held together by Empire. It was only once imperialism began to fail that the state would start to break up.

\section{SCOTTISH LABOUR AND RACE IN SOUTHERN AFRICA}

Kenefick and I do not differ in seeing the Scots as having had an important impact in southern Africa. The period of the revival of the world economy from two decades of depression in the early i 890 s to the regional economic slump of 1906 saw southern Africa become a major focus for Scottish emigration. The Scots were disproportionally well represented in British emigration to South Africa - one Scot to three English, as against one to seven in the UK population as a whole. ${ }^{18}$ Incredibly, there was a brief period in the mid-I890s when Scottish emigration to the southern African not only exceeded emigration to Australia, but even that to Canada! ${ }^{19}$

Moreover, there is no doubt that Scottish artisans and socialist activists, with their excellent technical skills, high levels of literacy, traditions of self-education, and strong history of political engagement, made a

14. Christopher Harvie, Scotland and Nationalism: Scottish Society and Politics 1707-1994 (London, I995), pp. 7-I I I.

I s. Devine, Scottish Nation, pp. 306-308.

16. Harvie, Scotland and Nationalism.

17. Tom Nairn, The Enchanted Glass: Britain and its Monarchy (London, 1994).

18. Harvie, Scotland and Nationalism, pp. i87-188.

19. Gordon Donaldson, The Scots Overseas (London, I966), pp. 187-188. 
contribution to South African labour unions and politics out of all proportion to their numbers. Figures like Christina and Robert Barnet, two forgotten Glaswegian political activists in the Transvaal who produced an intriguing local socialist newspaper, the Eastern Record, certainly deserve to be rescued from the oblivion to which South African labour history has consigned them. Scots trade unionists like James Thompson Bain, Andrew Watson, and David McKerrell were at the forefront of the major strikes by white workers in I9I3-1914 on the Rand (the goldmining area around Johannesburg). And there were local Scots activists, especially those adhering to the ideas of the American Industrial Workers of the World (IWW) and the Clydeside-based Socialist Labour Party (SLP) who did advocate a non-racial politics.

But where Kenefick's arguments mislead is in their implication that such anti-racist ideas reflected or influenced the racial views of large numbers of white (especially Scottish) immigrant workers. Although revolutionary syndicalists had, at times, some real influence on the struggle tactics of white workers, there is no evidence whatsoever that the mass of white workers were significantly influenced by the anti-racist ideas of this small group of activists. Before I9I4 white trade unionists in southern Africa, with only very minor exceptions, did not organize black workers.

At the centre of his evidence for the key role of the Scots in workingclass anti-racism, Kenefick places the work of the labour organizer, Archie Crawford. Crawford was certainly amongst the most interesting of the international labour organizers of the time. Archie Crawford came to South Africa as a soldier in the Boer War and eventually settled on the Rand. As Kenefick rightly points out, Crawford and his colleague James Davidson were amongst the outspoken opponents of white labourism. Crawford (together with his Irish partner and collaborator, Mary Fitzgerald) advanced a racially egalitarian position in their important (though small-circulation) newspaper, The Voice of Labour, published in Johannesburg from 1908-I9I2. ${ }^{20}$ In I9II, leaving Fitzgerald to run the paper, Crawford undertook a remarkable round-the-world trip, documented in the pages of the Voice, during which he visited many of the key syndicalist leaders in Australasia, North America, and Europe. Crawford and Fitzgerald played a crucial role in leading white workers in the I9I3 Rand strike, including producing a strike newspaper and directing a central Johannesburg crowd in the burning down of the main railway station and the offices of the mineowners' newspaper, The Star. A new general strike took place in

20. For a biographical overview on Crawford, Fitzgerald, Bain and the other major activists in this period see Jonathan Hyslop, "The British and Australian Leaders of the South African Labour Movement 1902-1914: A Group Biography", in K. Darian-Smith, P. Grimshaw, and S. MacIntyre (eds), Britishness Abroad: Transnational Movements and Imperial Culture (Melbourne, VIC, 2007), pp. 90-108. 
I9I4, following which Crawford was one of a group of leading trade unionists temporarily deported to the $\mathrm{UK} .^{2 \mathrm{I}}$

But Crawford's critique of white-labour politics did not reach the union membership. When Crawford stood in a white-franchise election on his full political programme, he got only a derisory handful of votes. Though Crawford was an able agitator, and the more militant elements of the Johannesburg strikers in I9I 3 did take inspiration from him, this only extended to the white trade unionists' work grievances and to the tactics of their violent clashes with the authorities. In I9I 3 and I9I 4 there was no mass support for Crawford's racial politics, and neither did he particularly take the opportunity to disseminate his views on the question amongst white workers. Furthermore, Crawford never did anything practical to promote trade unionism amongst black workers.

After returning from his brief deportation to Britain in I9I4, Crawford swung violently to the right, becoming part of the segregationist South African Labour Party (SALP) apparatus and leading the Transvaal Industrial Federation (a key union organization on white-labour lines). The man who had been the South African labour movement's most articulate and visible opponent of white labourism in the end actually succumbed to it. This, I would think, speaks of the strength of white labour ideology, rather than of the success of the campaign against it.

Kenefick also invokes the politics of the great founder of Scottish labour organization, James Keir Hardie, as an important source of opposition to labour racism in southern Africa, especially during his 1908 visit to the region. Hardie's earlier speeches attacking the Natal colonists' suppression of the 1906 Bambatha uprising in Zululand, and his advocacy, during his visit to India, of Indian self-government led to riots against him by jingoist mobs when he came to Natal and the Transvaal. (Contrary to Kenefick's attribution of these riots to resentment of Keir Hardie's non-racial trade unionism, it was the Indian and Zululand issues which primarily motivated the mainly middle-class, anglophone crowds which attacked him).

But Hardie's racial egalitarianism did not fit comfortably with the realities of South African labour politics. As I have shown in my article on Hardie's journey, in southern Africa he found himself in the difficult position of being supported and protected by trade unionists who admired his role in the British movement, but who mostly had far different views from him on race. ${ }^{22}$ Hardie felt constrained to present his views in a way which would gain the ear of his South African audience, and did not simply, as Kenefick says, urge the British immigrant unionists to open their 
unions to black people. When Hardie addressed a Johannesburg trade union audience in February 1908, he denounced the use of Chinese labour on the Rand mines as a betrayal of the British workers who had supported the I 899-1902 war effort. And while advocating the "rate for the job" regardless of race, he framed this as best for white workers' interests; if management did not have the option of cheap labour, he contended, between black and white workers who were paid the same, they would always choose the white. ${ }^{23}$ Hardie was indeed remarkable for his personal racial politics, but he was not able to operate outside of an engagement with white labourism.

There is a tendency in Kenefick's article to accept too easily examples of racial paternalism as a sign of anti-racialism, for example, when he cites the Scots-born Transvaal labour activist A.S. Raitt's no doubt genuine concern over the shocking conditions of black labour. But this misunderstands the way in which paternalism can be imbricated with racial domination. As Eugene Genovese showed for the case of slavery in the American South, ${ }^{24}$ and Charles van Onselen for farm labour in early twentieth-century southern Africa, ${ }^{25}$ paternalism can actually play a central part in systems of extreme racial inequality and can indeed combine emotional intimacy with violence.

In my analysis of the classic "English" socialist novel, The Ragged Trousered Philanthropist, written by the Irish labour activist "Robert Tressell" (Robert Noonan), I explained that sympathy with the condition of colonized people was, in sophisticated versions of white labourism, not seen as in opposition to racial labour protection. ${ }^{26}$ "Tressell", who spent the I89os living in Cape Town and Johannesburg, exalts the "natural" life and strength of pre-colonial peoples, and sees them as being ruined by industrialization. This trope then provides a moral rationale for white labourism. White labourists could now present their actions in excluding people of colour from the modern labour market as an altruistic protection of their way of life against capitalist exploitation. Tressell/Noonan was an important leader of the Trades Council in Johannesburg of the I89os, which took racial protectionist positions. There were ways in which white labourism could be rationalized with a "benevolent" view of the colonized - a classic paternalist move. Raitt was probably genuinely sorry for black workers, but he did not propose to give them the vote.

Kenefick suggests that I do not acknowledge the range of debate on race in the South African labour movement. I do recognize that there was

\footnotetext{
23. The Star, ig February 1908.

24. Eugene Genovese, Roll, Jordan, Roll: The World the Slaves Made (New York, 1974).

25. Charles van Onselen, "The Social and Economic Underpinning of Paternalism and Violence on the Maize Farms of the South-Western Transvaal, 1900-1950", Journal of Historical Sociology, s (1992), pp. I27-I6I.

26. Jonathan Hyslop, "A Ragged Trousered Philanthropist and the Empire: Robert Tressell in South Africa”, History Workshop Journal, 5 I (200I), pp. 64-86.
} 
such debate - but in that debate anti-racist positions were consistently defeated or marginal. Apparent exceptions pointed to by Kenefick do not always stand up to scrutiny. Thus, for example, Kenefick points out that the SALP conference of I9I I discussed the incorporation of "coloured" (in the South African sense of "mixed race") workers into the Party. But, as he himself concedes, this debate did not look at the position of African or Indian workers. And the debate was framed within an ideology that saw coloureds, but not other racial categories, as assimilable into the world of white standards. This should also be seen in the context that in the Cape Town area, where the largest number of coloured artisans resided, there was a tradition of white and coloured artisans working alongside each other, and a surprisingly wide acceptance by whites of the Cape's non-racial (but property-qualified) franchise which gave the vote to some coloured men. So the SALP's discussion did not mean particularly drastic change for white unionists, and only minimally strengthens Kenefick's arguments.

In my articles I have emphasized that British and Australian workers' influence was a key factor in generating labour racism. Kenefick, as I understand him, feels that in doing so I let Afrikaners off the hook, while exaggerating the Australian influence and traducing the British, especially the Scottish, contribution. For him, in noting that the first conference of the SALP was attended only by British-origin delegates, I absolve "the Afrikaner (and the influence of Afrikaner political ideology)" from "all responsibility for the formulation, production and distribution of the common ideology of white racism". But the fact is that Afrikaner leaders in the South African labour movement before I9I4 were as rare as hen's teeth. In all my research I have only found one Afrikaner (G. Kretschmar) and one Dutch immigrant pro-Afrikaner (H.J. Poutsma) in significant leadership positions in the labour movement in this period.

Between 1902 and 1914, Afrikaners did start to come into the mine labour force in significant numbers. But the big leap forward in Afrikaner numbers was when they were brought into the mines as scab labour in a I 907 strike, which was hardly conducive to their smooth integration into the unions. As time went by, Afrikaners become more involved in the labour movement, but even in the 1922 miners' "Rand Revolt", which did have a significant Afrikaner nationalist element within it and in which Afrikaners led some of the militarized defence groups organized by the strikers, the actual union leaders were overwhelming British- or Australianborn or South African white anglophones. ${ }^{27}$ The key segregationist industrial legislation was indeed enacted in 1924, under J.B.M. Hertzog's Afrikaner nationalist government, but this happened in coalition with, and at the 
urging of, the SALP. Hertzog appointed the SALP's leader, Colonel F.H.P. Cresswell, as Minister of Labour.

What Kenefick misses is that, at this stage of Afrikaner nationalism's development, opposition to British domination rather than "native policy" was the central concern. Early twentieth-century Afrikaner nationalists were certainly racist, but they were primarily interested in questions relating to their resentment of political subordination to London and the local socioeconomic dominance of British immigrant elites. Republican politics, language and cultural rights, and lack of representation in business ownership, the civil service, and the professions were their major concerns. It was not until 1929 that for the first time Hertzog made the Swart Gevaar (black danger) the leading issue in an election. None of this is to say that Afrikaner nationalism was not racist, but it is to say that imposing industrial segregation was not one of its most pressing concerns. The impetus for that came from the British immigrant-led unions and SALP. And the Hertzogites were not seriously interested in taking over unions for the nationalist cause. This only happened at the initiative of D.F. Malan's faction after it broke away from Hertzog in 1933-1934, and its real success only came with the Malanite capture of the white mineworkers' union in the $1940{ }^{28}{ }^{28}$

As for the Australian influence, it is apparent from the labour press of the era, in both the United Kingdom and South Africa, that British workers and socialists were much attracted by Australia's welfare state, and that few questioned the Australian belief that a "White Australia" policy had to be a central part of this model. The 1903-1907 campaign on the Rand against the importation of Chinese workers was led by an Australian, Peter Whiteside, who headed up the Trades and Labour Council. The TLC, which had a number of other Australian leaders, put forward arguments against allowing the Chinese into the country which were identical to those used in support of the White Australia policy, enacted in I90I. The Australian R.B. Waterston, a strong white labourist, emerged from obscurity on an East Rand mine during the I9I 3 strike, to become Secretary of the SALP. At the time of the passage of the most important segregationist industrial legislation in 1924, the SALP's parliamentary delegation included Whiteside, Waterston, and another Australian, J.J. Ware.

I have always accepted that amongst the white working class in South Africa in our period, there was an intense, and indeed rabid, class hostility to the mineowners. Kenefick tends to use the existence of such class identification to imply that somehow, if the labour movement was anticapitalist, it could not really have been racist. But this is a non-sequitur: there is absolutely no reason why anti-capitalist militancy cannot combine with 
extreme racism. The I9I 3 and I9I4 white workers' strikes were as militant and violent as any in United States or elsewhere in the Empire at the time, and the 1922 "Rand Revolt" with its intense street fighting between white miners and Smuts's army, and over 200 fatalities, far exceeded any other contemporary labour uprising in the US or the white-settler colonies in its militarization. However, this says nothing about resistance to racism.

In his brilliant recent work on the 1922 revolt, Jeremy Krikler has shown that the racial massacre during the strike was intrinsically linked to the politics of the rank-and-file strikers. ${ }^{29}$ The syndicalist and communist leaders of 1922 did try to oppose this racial pogrom, but were unable to restrain their supporters. This course of events would seems to provide further backing for the case that I have made about the lack of influence of anti-racist ideas on the mass of white trade unionists.

The relationship between white syndicalists and black workers changed significantly with the coming of World War I. In I9Is anti-war radicals in the SALP split away, forming the International Socialist League (ISL). A number of the leading syndicalists joined the ISL, but the bulk of the SALP's members did not, remaining with the party, under the pro-war leadership of Colonel Cresswell. From igis some of the immigrant syndicalists, especially those associated with the ISL, started to play a role in initiating black trade-union organization, which was to take off on a large scale by 19i 8-1919. As Van der Walt demonstrates, the ISL's politics was more syndicalist than proto-communist, and traces of syndicalism remained even after the ISL's merger into the new Communist Party in I92 I.

However, this activist, anti-racist organizing of black workers initiated by a handful of activists during the war years, was not something that gained substantial support from the mass of Scots or other white workers in the Rand labour movement. The ISL, especially after the Russian Revolution, began to attract the support of east European Jewish immigrants, and indeed this ethnic grouping became a significant portion of the Communist Party when it was formed. But linguistic and cultural barriers (and probably a degree of anti-Semitism) made it difficult for Jewish activists to influence the United Kingdom-born trade unionists.

\section{NATIONAL IDENTITY, RACE, AND LABOUR IN SCOTLAND}

How much support was there in Scotland for white labourism? ${ }^{3 \circ}$ I would argue that it became a central question in British politics, on both sides

30. Kenefick utilizes the work of Neville Kirk to argue that in the colonial context capitalism was more directly shaped by the interests of monopoly capitalism than in the metropolis. A central feature of this situation was the cheap labour of people of colour. According to Kirk and 
of the border. The Liberal Party's campaign against the use of Chinese labour in the Transvaal was one of the main factors contributing to its success in the elections of 1906 . Only the burning issue of imperial tariff protectionism versus free trade got more attention on the hustings. Although the Liberal campaign presented itself in humanitarian guise, denouncing "Chinese slavery", there can be no doubt that the racial sub-text of the campaign was defence of the white worker. And Labour certainly did not challenge that aspect of the Liberal rhetoric. (Although Labour made great strides in I906, the large bulk of enfranchized British working-class voters were still Liberals).

In the Cornish mining constituencies where a very large proportion of the electorate had either worked in southern African mines, or had relatives working there, the Liberals scored smashing victories by consolidating their base around the anti-Chinese policy. ${ }^{3 \mathrm{I}}$ And the Liberals, it should be noted, won Scotland in a landslide victory in I 906. ${ }^{32}$ It is quite naïve for Kenefick to quote, as evidence of labour antiracism, a speaker at the Glasgow rally in I9I4 that "their objections to Chinese and Indian labour was not because these men were of a different race and a different colour, but because they lowered the standard of life for white men". It was only too typical for white labourists to deny having racist intent before going on to advocate discriminatory measures.

The maritime industries provide an important example of the strength of support for white labourism amongst trade unionists in Britain. Kenefick questions my claims here by disputing my use of the example of maritime labour organizer O'Connor Kessack's agitation against the use of Chinese labour in the British shipping industry. Kenefick concedes the racist character of Kessack's interventions, but claims that there was much opposition to his racism. Yet it remains the case that Kessack was able to

Kenefick, the British metropolitan working class was not in the same competitive position in relation to African and Asian labour and did not have any sympathy with white labourism. In invoking Kirk's views, Kenefick somewhat gives the impression that I am out on a limb in relation to current scholarship. But the recent and path-breaking work on racial ideology in the British Empire in this period, Marilyn Lake and Henry Reynold's Drawing the Global Colour Line, comes to broadly similar conclusions to my own, accepts a connection between the white working classes and racial labour exclusionism, and, in fact, specifically endorses my "white labourist" argument. So my position is not quite as eccentric as Kenefick implies. See Neville Kirk, Comrades and Cousins: Globalisation, Workers and Labour Movements in Britain, the USA and Australia from the I880s to 1914 (London, 2003), and Marilyn Lake and Henry Reynolds, Drawing the Global Colour Line: White Men's Countries and the Challenge of Racial Inequality (Cambridge, 2008).

31. Richard Dawe, Cornish Pioneers in South Africa: Gold and Diamonds, Copper and Blood (St Austell, 1998), pp. 193-224.

32. Devine, Scottish Nation, p. 303. 
draw a huge crowd of Glasgow workers to a I9I4 rally advertised under the slogan "Chinese Invasion of Britain". ${ }^{33}$

As I have shown in a recent article on racial politics in the British merchant marine, in the late nineteenth and early twentieth century British seamen focused very much of their organizational effort on excluding African and Asian labour. ${ }^{34} \mathrm{~J}$. Havelock Wilson's National Union of Seamen and Firemen (NUSF), which was a major power in British trade unionism, was the main force in this campaign. The extent of xenophobia in the union was reflected in the I9I I anti-Chinese riots in the port of Cardiff, which Havelock Wilson's lieutenant, "Captain" Edward Tupper, boasted of having personally organized. ${ }^{35}$ Kenefick cites Scottish labour leader John Wheatley's public attack on Kessack and Wilson to dramatize the opposition to them from the left. But, as far as I am aware, such opposition was based on Wilson and Kessack's lack of militancy in behalf of their British members and did not involve an attack on their policies of racial exclusion.

Kenefick also quotes Irish syndicalist Jim Larkin from the same meeting as saying that he stood on a platform broad enough to accommodate "the Scottish and Irish workers [...] the Saxon and any other race. It was the platform of human liberty." Kessack was a notorious religious bigot, and Larkin was no doubt attacking him for fomenting Protestant-Catholic division. At the time different European nationalities were frequently spoken of as "races". So there is not a clear indication that Larkin was including African and Asian labourers in his global fraternity. It is more likely that he was simply calling for unity between Ireland's two ethnic/religious factions.

In arguing for the anti-racist thrust of the politics of the British labour movement, Kenefick cites the anti-colonial resolutions passed in this period by the Social Democratic Foundation (SDF) and the British Socialist party (BSP). There were indeed a number of important anticolonial activists in these groups. But the SDF, despite its historic importance as Britain's founding Marxist party, was a small and declining sect, increasingly marginalized by the Independent Labour Party (ILP) from the I 890 , and by the parliamentary Labour Party from the time of its success in the 1906 election. The BSP, founded in I9II, despite recruiting a number of important Scottish activists, never became a mass organization, and split over whether or not to support the war effort in I9I4. So the resolutions pointed to by Kenefick do reflect what a core of Scottish activists thought, but are not evidence of broader Scottish 
working-class opinion. The ILP and Labour Party steadily grew in support while the SDF and BSP never achieved any electoral success.

It is also debateable, insofar as there was anti-imperialism amongst the Scottish and English working class, to what extent the left could take credit for this. Radical Liberals had a strong tradition of opposition to militaristic forms of British expansion, and had enjoyed considerable mass support for this stance. This was particularly the case in Scotland: in I 879, William Ewart Gladstone, during his crucial election campaign in Midlothian, made the imperial adventures of the Disraeli government in southern Africa and Afghanistan one of the foci of his attacks, to great popular acclaim. Gladstone told his audience that the Zulus had been slaughtered "for no other offence than their attempt to defend against your artillery, with their naked bodies their hearths and home, their wives and families" and that "the sanctity of life in the hill villages of Afghanistan among the winter snows, is as inviolable in the sight of almighty God as may be your own". ${ }^{36}$

This kind of powerful rhetoric, however belied by the Grand Old Man's performance in office (which included absorbing Egypt into the Empire) undoubtedly formed the opinions of some of those Liberals who later transferred their allegiance to the Labour Party. Radical liberals, rather than socialists were at the forefront of the protests against the South African War, with Scottish Liberal MPs taking a particularly prominent part in opposing the war. ${ }^{37}$ Keir Hardie did play a part in this campaign, but while liberals and socialists justifiably denounced the unscrupulous British manipulation leading to the war, both tended to idealize the Boers and to ignore the racial inequalities of the Boer states.

Some of Kenefick's criticism of my work focuses specifically on my analysis of the response of the British labour movement to the deportation of nine Johannesburg strike leaders (including Crawford, Bain and Watson) to Britain in I9I4. Kenefick is not convinced by my argument that the extent to which white workers had been subject to repression in South Africa was seen as a breaching of the thresholds of violence which could be acceptably used against white British citizens, or by my emphasis that British labour leaders primarily attacked the South African government in terms of the unconstitutionality of its actions. Here, it seems, Kenefick is uncomfortable with the extent of identification with the Empire amongst labour and socialist leaders that my position suggests, and the racial double standards in their thinking that this implies. Yet in reading primary labour-movement sources on the issue, it is quite

36. Roy Jenkins, Gladstone: A Biography (New York, I997), p. 420.

37. W. Hamish Fraser, Scottish Popular Politics: From Radicalism to Labour (Edinburgh, 2000), pp. I4I-I 43 . 
impossible to get away from a discourse in which British birth was seen as conferring a particular legal privilege, and the constitutional rights of Britons as a crucial idea to defend.

The whole critique of the government's actions was rooted in ideas of Britishness. The Labour Party leader, James Ramsay MacDonald, in his first response to the deportations described them as "a disgrace to the British Empire and a violation of every civic right", ${ }^{8}$ and those who were more radical than he never directly challenged this framing of the issue. The levels of repression used by Botha and Smuts against white, British-born workers evoked responses amongst labour which simply would not have been produced had they been used against colonial peoples. Smuts's use of martial law against white British subjects was highly unusual in British practice, ${ }^{39}$ and did produce genuine outrage, not only amongst labour activists. It was precisely because white British-born workers were on the receiving end that the South African government's action provoked such anger.

Consider for example, another, exactly simultaneous development in South Africa. In November I9I 3 several thousand Indian miners from Natal, and their families, led by M.K. Gandhi, entered the Transvaal province illegally in a protest against their working conditions and discriminatory legislation. The workers were imprisoned in the mines with hard labour and flogged if they refused to work. The difference between the muted British labour response to Gandhi's protest, and the I9I4 labour demonstration in Hyde Park in support of the deportees, reckoned by many contemporaries to be the biggest ever, illustrates precisely the racialized nature of British labour solidarities.

Kenefick objects to my suggestion that the imperial working class was forced to close ranks because it saw that a greater threat came from "all the social forces that could be represented as non-British"; not simply Africans and Asians "but also white 'others". Specifically, he is keen to dispute my contention that anti-Semitism was widespread in the ranks of British and Scottish labour. He particularly deplores my citation of an illustration in the Glasgow Independent Labour Party paper, Forward, in which a Rand mineowner in the foreground was depicted as what I called "a stereotypical, fat Jewish capitalist" warmly embracing an armed Boer militiaman, while standing forlornly in the background is what I described as a "clean-cut manacled [white] worker". Kenefick says, probably correctly, that all cartoon capitalists at the time were depicted as fat. But this does not get us away from the fact that the facial features of the cartoon character represents the worst kind of hostile stereotyping of Jews.

\section{The Daily Telegraph, 30 January i914.}

39. Jonathan Hyslop, "Martial Law and Military Power in the Construction of the South African State: Jan Smuts and the 'Solid Guarantee of Force' i 899-1924”, Journal of Historical Sociology, 22 (2009), pp. $235^{-268 .}$ 
It was the case that the Boer War was widely characterized by its opponents, both liberal and socialist, as an action by the British government in support of Jewish capitalists on the Rand. Such innuendo continued in the socialist press throughout the period before I9I4, and can be picked up in any careful reading of publications like Forward, or in English socialist publications popular in Scotland like the Clarion or the Daily Herald. Would Kenefick really want to deny, for instance, that the following doggerel, published in the Forward in January I9I4, is anti-Semitic:

Chorus of Eckstein, De Beers, Barnato, Joel, Hertzog, Smuts, Botha, Israel Goldstein, Hoggenheim and company:

"Hoch! Hoch! For Martial law! None may arraign

Our villainy, when loyal Burgher bands

Shoot British workmen down". ${ }^{\circ}$

Kenefick is right to suggest that Jewish immigrants in Scotland were far better received than in many other parts of the world. But this does not add up to an absence of anti-Semitism. One has only to open the pages of the immensely popular novels of John Buchan to see how shockingly socially acceptable a low key anti-Semitism was in early twentieth century Scotland. ${ }^{4 \mathrm{I}}$

Stephen Howe has shown that there was a distinct shift in British labour organizations as a whole toward an anti-colonial position after World War I. ${ }^{42}$ But this development should not be projected back to the pre-I9I4 period. When Kenefick cites miners' leader Bob Smillie's invocation of class war in "America, British Columbia, South Africa" he does not help his case. For in the previous decade, in British Columbia the exclusion of Asian immigrants from the province had been the chief demand in the labour movement, while in California labour had run a large-scale campaign against Japanese immigrants. ${ }^{43}$

\section{CONCLUSION}

If the core of the Kenefick's argument is that, as he puts it in his introduction that "the creed of 'white labourism' was not accepted by all imperial workers", then we do not differ. I agree that there were opponents of white labourism in the British and diasporic labour movements. Where we are empirically at odds is over the extent of and mass support

\footnotetext{
40. Forward, 24 January I9I4.

4I. In an otherwise excellent book, Buchan's most recent biographer struggles unsuccessfully to explain away his protagonist's quite evident anti-Semitism: see Andrew Lownie, John Buchan, the Presbyterian Cavalier (London, 1995).

42. Stephen Howe, Anticolonialism in British Politics: The Left and the End of Empire 19I8-1964 (Oxford, I993).

43. Lake and Reynolds, Global Colour Line, pp. I66-189.
} 
for such non-racial activism. However, I think there is a deeper question which underlies this dispute, which centres around how we view the imperial world. In support of his position, Kenefick invokes Neville Kirk's argument the that the Australian and South African labour movements were racialist whereas the metropolitan British one was not. ${ }^{44}$ He also draws on Bernard Porter's argument that colonial labour disputes were only taken up by the British left as labour issues and not racial ones. ${ }^{45}$ Both these positions are examples of what I would call imperial denialism, that is to say, the unwillingness to recognize that every aspect of metropolitan society was saturated with the effects of Empire, and especially those relating to race. In this particular case imperial denialism is underpinned by the sentimental tendency of historians of British labour to romanticize the movement.

One can certainly accept that the white workers of the Empire often felt genuinely threatened by racialized cheap labour competition without having to deny that the policies they propounded to address this were racist in ideology and in practice, or to treat the "economic" as mysteriously distinct from other forms of social action. In the Age of Empire, anti-capitalism and racism could be, and often were, partners. 